\title{
Macro-Prudential Policy AND THE CONDUCT of Monetary Policy
}

\author{
Denis Beau \\ Banque de France \\ Christophe Cahn \\ Banque de France \\ Laurent Clerc \\ Banque de France \\ Benoît Mojon \\ Banque de France
}

The "Great Contraction" in global economic activity triggered by the financial crisis, and the extraordinary fiscal and monetary measures that public authorities had to undertake in order to put the economy back on track by putting public finances under heavy strains and leading to extremely low short-term interest rates, have shown the enormous costs resulting from an unstable financial system.

Such costs have triggered wide-ranging reviews of financialstability policies. An important outcome of such a review is the strengthening of policies and instruments focused on macro-financial stability, the so-called "macro-prudential policies."

The deployment of such policies may however raise important coordination issues with other stability-oriented policies, ranging from micro-prudential to monetary policies. Such coordination issues

This paper benefited from the efforts of several colleagues from the Banque de France Monetary Policy Division (POMONE). We are particularly grateful to Pamfili Antipa, Julien Matheron and Eric Mengus. We are also grateful to Jean-Pierre Landau and Pierre Jaillet for comments and suggestions on earlier drafts. The views expressed in this paper are those of the authors and do not necessarily reflect the views of the Banque de France. All remaining errors are ours.

Macroeconomic and Financial Stability: Challenges for Monetary Policy, edited by Sofía Bauducco, Lawrence Christiano and Claudio Raddatz. Santiago, Chile. (C) 2014. Central Bank of Chile. 
stem from the interdependencies between these policies, in terms of both objectives and transmission mechanisms.

The aim of this paper is to explore the coordination issues specifically raised by the cyclical effects of macro-prudential and monetary policies. ${ }^{1}$ Under this perspective, we address the following two questions: First, do the likely interactions between macroprudential policies and monetary policy create a risk of conflicts in the pursuit of financial stability and price stability? Second, how large is this risk?

The paper is organized as follows. In section 1, we discuss the possible interactions between macro-prudential and monetary policies; whereas, in section 2 , we present results from simulations conducted with a DSGE model estimated using time series of euro area macroeconomic variables over the period 1985-2010. These simulations allow us to assess the circumstances under which macro-prudential policies may have compounding, neutral or conflicting outcomes that interfere with the pursuit of price stability by monetary policy.

\section{The Interactions between Macro-Prudential and Monetary Policies and the Risk of Conflicting Impact on Financial and Price Stability}

\subsection{The New Role of Macro-Prudential Policies in Financial-Stability Oriented Regulatory Frameworks}

The financial crisis has shown that neither market discipline nor regulation and supervision of the financial system's main components (i.e. institutions, markets and infrastructures) can prevent systemic risk, i.e. the risk that disruptions to financial services' activities may have serious negative consequences on the stability of the financial system as a whole, and therefore on the real economy.

1. The objective of macro-prudential policies are both preventing the build-up of systemic risk, and mitigating its impact on the economy. There are two dimensions to this: First, improving the resilience of the financial system, by limiting the contagion effect due to "bank runs," asset fire sales and externalities phenomena, improving infrastructures and monitoring aggregate risk. Second, limiting the risk of spillovers of financial instability on the business cycle and the real economy. In this paper, we focus exclusively on this second dimension of macro-prudential policies, which are the most likely to interfere with monetary policy's goal to stabilize prices. 
In order to better limit the likelihood and impact of systemic risk, a reform of the international regulatory framework is underway. Its objective is to better guarantee the stability of the financial system as a whole, not just of its components. ${ }^{2}$ A key element of that reform, beyond strengthening the supervision of individual financial institutions, the oversight of key market infrastructures and the monitoring of the functioning of financial markets, is the strengthening of the role of so-called "macro-prudential" policies, namely policies that focus on the interactions between financial institutions, markets, infrastructure and the business cycle. ${ }^{3}$

In September 2010, the Basel Committee for Banking Supervision (BCBS) proposed an important step in the reform of the international regulatory framework. The G20 leaders endorsed such proposal at their Seoul summit in November 2010. Beyond significantly strengthening micro-prudential requirements in terms of capital, liquidity and leverage, the BCBS agreed on the introduction of a so-called "macro-prudential overlay," ${ }^{4}$ wich has two dimensions.

First, it seeks to reduce the banking system's tendency to amplify the ups and downs of the business cycle through the excessive credit supply and excessive credit cutbacks, which typically arise in periods of financial exuberance and financial stress, respectively. Tools to be used to that effect notably include a capital conservation, which will prevent banks from making inappropriate distribution when their capital declines, and a countercyclical capital buffer, which will compel banks to increase their capital base during periods of excessive credit growth.

Second, it seeks to limit the transmission of shocks across the financial system. Tools to be used to that effect are still being debated, but they will most likely combine capital surcharge, bailin debt and contingent capital for systemically important financial institutions (SIFIs).

2. See H. Hannoun: "Towards a global financial stability framework." 45th SEACEN Governors' Conference, 26-27 February 2010.

3. See CGFS "Macro-prudential instruments and frameworks: a stocktaking of issues and experiences." May 2010.

4. See N. Wellink "A new regulatory landscape," 16th International Conference of Banking Supervisors, 22 September 2010. 


\subsection{Coordination within the New Institutional Arrangements}

Box 1 below presents the main features of the new institutional arrangements recently adopted in Europe, the U.S., and the U.K.. While the three setups are somewhat different in nature, it must be noted that each of them has been designed so as to allow an effective coordination and information sharing amongst the central banks and the authority in charge of the macro-prudential policy.

\section{Box 1. InSTITUTIONAL ARRANGEMENTS IN THE U.S., THE U.K., AND THE E.U.}

The responses to the crisis in terms of macro-prudential regulation have been quite heterogeneous across different jurisdictions. On one hand, the Financial Regulation Bill (also referred to as the Dodd-Frank Act) which was approved by the U.S. Senate in July 2010, has created a new Financial Stability Oversight Council (FSOC), headed by the Treasury Secretary and independent from the Fed. On the other hand, the U.K. Treasury presented, in July 2010, a proposal for reforming the tripartite model, which led to the inception of a new Financial Policy Committee within the Bank of England with primary statutory responsibility for maintaining financial stability. In Europe, following the recommendations of the de Larosière report, the European Commission has created a European Systemic Risk Board (ESRB), which came into force on December 16, 2010 and which, like its U.S. counterpart, is independent from the European Central Bank. By contrast to its U.S. counterpart, however, the ESRB is not provided with the full control of macro-prudential tools.

In the U.S., the Dodd-Frank Act and the Consumer Protection Act adopted in July 2010 are probably the most extensive pieces of financial services regulation since the Great Depression. The Dodd-Frank Act creates a new interagency council, the Financial Stability Oversight Council (FSOC), but also establishes a new system for the liquidation of certain financial companies; it provides for a 
new framework to regulate derivatives; it establishes new corporate governance requirements; and it regulates credit rating agencies and securitization. The FSOC is in charge of identifying, monitoring and addressing systemic risks posed by large and complex financial firms, and of making recommendations to regulators. It is also be tasked with monitoring domestic and international regulatory proposals, facilitating information sharing among financial services regulators, designating non-bank financial companies as systemically important, and providing recommendations to the Federal Reserve Board on prudential standards. It is able to provide direction to, and request data and analyses from, the Office of Financial Research (OFR). Being within the treasury department, this office contributes to improving the quality of financial data available to policy-makers and providing analytical support to the FSOC. It should also develop a reference database easily accessible to the public, in order to maximize data efficiency and security, by coordinating with regulators, both domestically and internationally. Finally, it should standardize financial reporting requirements.

In performing its tasks, the FSOC is therefore completely independent from the Fed. Interestingly, in addition to its current oversight responsibilities, and in order to mitigate risks to the financial system from large, interconnected financial institutions, the Fed is directed to establish prudential standards of its own or at the FSOC's recommendations. That is, the Fed is entrusted with autonomous macro-prudential tools on top of its dual monetary policy mandate.

In the U.K., recognizing serious failures in their tripartite regulatory system, authorities took a major step in order to change their regulatory framework, transferring operational responsibility for prudential regulation from the FSA to a new subsidiary of the Bank of England. In addition, a new Financial Policy Committee has been created within the Bank of England with the responsibility for maintaining financial stability. This committee works internationally with similar systemically focused authorities and with the ESRB to coordinate macro-prudential policies. The aim of 
this reform is to bring together responsibility for macro- and micro-prudential regulation within a single institution, i.e. the central bank.

To some extent, the European way is halfway between the U.S. and the U.K. approaches. Like in the U.S., the ESRB is an interagency council, independent from the ECB and only focused on macro-prudential policy. On the other hand, the inception of the ERSB is drawing heavily from the knowledge and the experience of the Eurosystem. Additionally, the ECB provides the ESRB with analytical, statistical, administrative and logistical support. National central banks and supervisors also provide technical advice, which constitute an important input into the work of the ESRB.

A major difference with the U.S. and the U.K. is, however, the lack of effective and autonomous regulatory tools. In effect, the ESRB will only have the possibility of issuing warnings and recommendations. The institutional arrangement, which has brought central bank governors and heads of supervision together since January 2011, should ensure both effective coordination and information sharing. The ESRB is tasked with identifying and measuring systemic risk. It has been mandated to develop a "risk dashboard," prioritize these risks, conduct top-down stress tests when appropriate, and finally propose policy responses through warnings and recommendations. These however cannot designate individual financial institutions.

Its tools are based on the obligation to "comply or explain." Therefore, even though the ESRB does not have formal directive power and the comply-or-explain obligation is not legally binding, such recommendations should have considerable moral force. The effectiveness of these recommendations may be considerably strengthened if they are made public.

In the U.S., the Financial Stability Oversight Council (FSOC) is independent from the Fed and is chaired by the U.S. Treasury. The Fed, however, participates jointly with other regulators in the FSOC 
and supports the Council's mission to prevent and address risks to financial stability. Such an involvement makes sure that the threats and the efforts to mitigate systemic financial risk effectively inform the conduct of monetary policy. It should however be noted that the Fed is still directed to establish prudential standards of its own and that it is entrusted with autonomous macro-prudential tools on top of its dual monetary policy mandate.

In Europe, the European Systemic Risk Board is distinct and separate from the ECB. It neither changes the monetary policy mandate, nor the functioning of the ECB, nor that of any national central bank in the E.U. However, the ECB plays a pivotal role in the new framework. The presence of the governors of all E.U. central banks in the Board of the ESRB, and the appointment of the ECB's president as the Chair of the ESRB, assign a pivotal role to the authorities in charge of monetary policy in the support of the ESRB. The joint participation of central banks both in the ECB's governing council and the ESRB Board should greatly facilitate coordination and the exchange of information between the two institutions.

Finally, in the U.K., the new Financial Stability Committee has been created within the Bank of England. It is separate from the Monetary Policy Committee and has an overall membership of 11, including internal members from the Bank of England. The remaining five members are from outside the bank, including a Treasury representative. This new committee is chaired by the governor and includes the deputy governors in charge of monetary policy and financial stability, and the newly created deputy governor of prudential regulation. Here, once again, the framework insures that the monetary policy decisions will effectively be fully aware of the macro-prudential policy design and implementation. Coordination is facilitated by having the governor of the bank chairing both the financial and the monetary policy committees. The reform acknowledges that a significant challenge for the bank will precisely be to manage this interaction between two statutory objectives and it has already made some proposals to do so. Under this respect, an important aspect is the sequencing of the meetings in order to make sure both committees will be able to fully take into account the most recent decisions taken by the others.

An important aspect of the coordination process relies of the information flows and sharing between the responsible institutions or committees. The U.S. authorities indeed established a specific institution (the OFR, see box 1 above) to cope with this 
issue. Information sharing between the monetary and macroprudential authorities is in that context of paramount importance. Considerations of data availability place central banks in an ideal position as key information providers in the field of macro-prudential policies due to the enormous amount of data they already collect for the conduct of monetary policy.

\section{Remaining challenges}

The dilution of responsibilities amongst authorities and the associated risk of "territorial" disputes can be addressed, or at least limited, by a clear assignment of objectives and tools. As a matter of fact, the simulations presented in section 3 clearly suggest that the conduct of monetary policy should keep a primary objective of maintaining price stability. Hence, the macro-prudential policy should not rely on monetary policy to preserve financial stability.

Ideally, the design of the macro-prudential policy objectives should preserve the independence of monetary policy making, facilitate coordination between the two policies, limit conflicts of objectives and clarify how these can be resolved when they occur.

First, the new macro-prudential objectives should be fully compatible with the monetary policy mandate in the following sense. It should neither jeopardize the primary objective of price stability for monetary policy nor put the central bank's independence in their pursuit for price stability at risk. ${ }^{5}$ That inflation expectations remained firmly anchored throughout the most severe financial crisis in 80 years has proven to be a considerable asset in the management of crisis. This asset, which builds on the clear mandate of monetary policy, the operational independence of central banks and their track record, should not be put at risk. In addition, the interferences with the conduct and the implementation of monetary policy should be limited to the maximum possible extent.

Second, clarity about the objectives of macro-prudential policies should be provided ex ante. The new regulatory frameworks tend to favor institutional setups involving several institutions or layers. This should imply close coordination between entities in charge of micro- and macro-prudential regulations on one hand, and between macro-prudential policies and other macroeconomic policies-

5. We refer here to the situation of Europe. In the case of the U.S., the Fed's monetary policy has a dual mandate of price stability and full employment. 
monetary and fiscal policies in particular-on the other. Therefore, clear objectives would minimize the potential for macro-prudential policies to undermine the responsibility for the objectives relevant to micro-prudential supervision, and fiscal and monetary policies. The extent and the nature of the collaboration amongst the various agencies involved in macro-prudential regulation in the financial crisis management phase are primarily shaped by how the different responsibilities for supervision and regulation, bank resolution, the provision of public guarantee and solvency support are allocated.

Finally, in circumstances where monetary policy and macroprudential policy objectives may be temporarily in conflict, accountability requires that such a conflict be publicly acknowledged. Policy bodies should be transparent to the extent of how policy decisions factor in trade-off between objectives. The common objective should be to strike the right balance between the short-term costs of financial stability and long-term costs of price instability, for example, as explained in Carney (2009) as the de-anchoring of inflation expectations.

In practice however, it should be stressed that an accountability framework of macro-prudential authorities will be more difficult to design than the one for monetary policy authorities. To begin with, as of today, we have neither a quantitative, nor (some may even say) a qualitative definition of financial stability, nor can we rely on an operational definition of systemic risk. This is in sharp contrast with the widely agreed definition and measurement of price stability on the basis of consumer price indices.

Recent research has focused on developing measures of systemic risk and means of allocating such risk to financial institutions (see for instance Engle and Brownlees, 2010). However, the construction of financial stability indices (see Hollo, Kremer and Lo Duca, 2010) is still in its infancy. Moreover, the goal of this research is more to provide new indicators than operational or quantitative targets to be assigned to macro-prudential authorities. The parallel with the monetary policy framework, as it has been designed over the last two decades, although tempting, is still very remote as far as macroprudential policy is concerned.

\subsection{The Interdependencies between Macro-Prudential and Monetary Policies}

Macro-prudential and monetary policies pursue two different objectives, namely financial stability and price stability. Following 
the standard Tinbergen principle, two separate (sets of) instruments allow authorities to implement the two policies. Turning to the allocation of instruments to objectives, the Poole (1970) principle of comparative efficiency provides the natural analytical benchmark. There is a broad consensus that monetary policy tools (e.g. central bank money supply conditions) are the natural ones for pursuing price stability. Additional tools, such as time-varying, countercyclical capital requirements should be used to implement macro-prudential policies that will help to preserve financial stability. This is consistent with the "principle of effective market classification" made popular by R. Mundell (1962) according to which, "Policies should be paired with the objectives on which they have the most influence."

In principle, such an allocation of policy instruments to the two objectives would limit the need of policy coordination. In practice however, having two separate sets of instruments may not necessarily prevent situations in which they interact, and may therefore have compounding or conflicting effects on the objectives they pursue. Moreover, the literature also points out that fully optimal policy would call for coordination when spillovers are large enough.

In this paper we take the view that the implementation of macroprudential policies will at the very least impact upon, and therefore alter, the transmission mechanism of monetary policy. The main reason for this is that macro-prudential policies will (partly) work through the very same transmission channels as monetary policy, the most likely being the bank lending and the balance sheet channels (see table 1 below for an overview) and-exactly as monetary policyare intended to modify private agents' behavior.

The likelihood of an interaction between macro-prudential and monetary policies originates from the focus of macro-prudential policies on monetary and financial institutions. ${ }^{6}$ These institutions turn out to be central banks' counterparts in their provision of liquidity to the economy.

6. The scope of macro-prudential policies should in principle be broad, as regulations currently under preparation shall make the new regulatory agencies responsible for the macro-prudential oversight of all types of financial intermediaries, including the shadow banking system, markets, products and infrastructures. However, collecting comprehensive information and assessing the financial risk on all these dimensions may prove challenging. By focusing on the regulated sector, but monitoring the links between the regulated and the unregulated parts of the financial system, through contingent credit lines, franchises, out-of-balance sheet movements or agreements etc., the macroprudential authority should have an effective lever on the whole financial system. 
Table 1. Macro-prudential Instruments and Monetary Policy Transmission Channels

\begin{tabular}{|c|c|c|c|c|}
\hline Vulnerability & \multicolumn{2}{|c|}{$\begin{array}{c}\text { Financial system } \\
\text { component }\end{array}$} & $\begin{array}{c}\text { Envisaged } \\
\text { macro-prudential tool }\end{array}$ & $\begin{array}{c}\text { Transmission } \\
\text { channels }\end{array}$ \\
\hline \multirow[t]{5}{*}{ Leverage } & \multirow[t]{2}{*}{$\begin{array}{l}\text { Bank / } \\
\text { Deposit } \\
\text { taker }\end{array}$} & Balance sheet & $\begin{array}{l}\text { - Capital ratio } \\
\text { - Risk weights } \\
\text { - Provisioning } \\
\text { - Profit distribution } \\
\text { restrictions } \\
\text { - Credit growth cap }\end{array}$ & $\begin{array}{l}\text { Bank lending } \\
\text { Broad credit } \\
\text { Balance sheet }\end{array}$ \\
\hline & & Lending contract & $\begin{array}{l}\text { - LTV cap } \\
\text { - Debt service/income cap } \\
\text { - Maturity cap }\end{array}$ & Bank lending \\
\hline & \multicolumn{4}{|c|}{ Non-bank investor } \\
\hline & \multicolumn{2}{|c|}{ Securities market } & - Margin/haircut limits & Collateral \\
\hline & \multicolumn{4}{|c|}{ Financial infrastructure } \\
\hline \multirow[t]{5}{*}{$\begin{array}{l}\text { Liquidity or } \\
\text { market risk }\end{array}$} & \multirow[t]{2}{*}{$\begin{array}{l}\text { Bank / } \\
\text { Deposit } \\
\text { taker }\end{array}$} & Balance sheet & $\begin{array}{l}\text { - Liquidity/reserve } \\
\text { requirements } \\
\text { - FX lending restrictions } \\
\text { - Currency mismatch } \\
\text { limit } \\
\text { - Open FX position limit }\end{array}$ & $\begin{array}{l}\text { Bank lending } \\
\text { Balance sheet }\end{array}$ \\
\hline & & Lending contract & - Valuation rules & $\begin{array}{l}\text { Balance sheet } \\
\text { Collateral }\end{array}$ \\
\hline & \multicolumn{2}{|c|}{ Non-bank investor } & $\begin{array}{l}\text { - Local curr. or FX } \\
\text { reserve requirements }\end{array}$ & Balance sheet \\
\hline & \multicolumn{2}{|c|}{ Securities market } & $\begin{array}{l}\text { - Central banks balance } \\
\text { sheet operations }\end{array}$ & $\begin{array}{l}\text { Collateral } \\
\text { Portfolio }\end{array}$ \\
\hline & \multicolumn{2}{|c|}{ Financial infrastructure } & - Exchange trading & \\
\hline \multirow[t]{5}{*}{$\begin{array}{l}\text { Inter- } \\
\text { connectedness }\end{array}$} & \multirow{2}{*}{$\begin{array}{l}\text { Bank / } \\
\text { Deposit } \\
\text { taker }\end{array}$} & Balance sheet & $\begin{array}{l}\text { - Capital surcharge for } \\
\text { SIFIs }\end{array}$ & Bank lending \\
\hline & & Lending contract & & \\
\hline & \multicolumn{4}{|c|}{ Non-bank investor } \\
\hline & \multicolumn{4}{|c|}{ Securities market } \\
\hline & \multicolumn{2}{|c|}{ Financial infrastructure } & - Central counterparty & Interest rate \\
\hline
\end{tabular}

Source: CGFS (2010) and Banque de France. 


\subsection{The Risks of Conflicting Interactions}

Whether macro-prudential and monetary policies may have complementary, conflicting or independent outcomes on financial and price stability will depend on the type and diffusion of supply and demand imbalances across the financial system and the real economy (table 2).

A typical example of a conflicting impact would be a situation in which an asset bubble has been identified, while there are strong risks to price stability on the downside. In other words, supply and demand are misaligned in both the financial system and the real economy, but in opposite directions. In that case, macro-prudential policy should aim at restricting credit and liquidity growth, but this could lead to an undesired contraction in aggregate activity, and to increased downside risks to price stability. The macro-prudential policy would then contribute positively to meet the financial stability objective, but would have an adverse impact on the price stability objective, calling for a policy response, possibly a loosening of the monetary policy stance.

Such a loosening of the monetary policy stance, however, may in turn have an adverse impact on the financial stability objective. Lower interest rates could indeed contribute to the build-up of financial imbalances via the so-called "risk-taking" channel. ${ }^{7}$ Simply put, very low interest rates may create incentives for banks to take on more risk through the interplay of various channels including asset substitution, search for yield, pro-cyclical leverage and risk shifting ${ }^{8}$ when banks operate under asymmetric information and limited liability.

Recent research has provided empirical evidence in favor of the existence of such a channel. It has been documented, ${ }^{9}$ for example, how market-based measures of banks' risks (as perceived by financial market participants) tend to react positively to changes in interest rates so that a lower interest rate leads investors to perceive banks as comparatively less risky. By the same token, several paper, have shown that credit standards are correlated with the level of interest rates: lower interest rates, in particular, imply lower credit standards

7. See Rajan (2005) and Borio and Zhu (2008).

8. See De Nicolo et al. (2010).

9. See Altunbas, Gambacorta and Marques (2010). 
including to customers who are perceived as representing a higher credit risk. Research carried out at the Banque de France ${ }^{10}$ has shown that when the regulatory environment is not transparent, a decrease in the level of the real interest rate increases banks' risktaking behavior, partly because it may facilitate the under-pricing of risks, which is typical when asset prices rise.

An alternative channel through which low rates may contribute to the building up of financial imbalances originates from central banks' ultimate focus on goods and services' prices rather than on asset prices. During the pre-subprime crisis period, characterized by big supply shocks originating from the integration of large developing countries into the global economy, the resulting disinflationary pressures induced central banks to keep nominal interest rates at historically low levels, which, with the benefit of hindsight, may have contributed to excessive credit growth, with the resulting creation of asset price bubbles. ${ }^{11}$

Overall, Mundell's separate-assignment principle for formulating monetary and macro-prudential policies should therefore not be understood as necessarily implying that coordination is not needed. On the contrary, it should lead to the conclusion that monetary policy decisions need to take into account the macroeconomic effects of macro-prudential policies and vice versa. ${ }^{12}$ In section 3 we resort to estimated DSGE models to illustrate this point.

Table 2. Likely Instances of Conflicts between Monetary and Macro-Prudential Policies

\begin{tabular}{lccc}
\hline & $\begin{array}{c}\text { Inflation } \\
\text { above target }\end{array}$ & $\begin{array}{c}\text { Inflation } \\
\text { close to target }\end{array}$ & $\begin{array}{c}\text { Inflation } \\
\text { below target }\end{array}$ \\
\hline Financial exuberance (boom) & Complementary & Independent & Conflicting \\
No imbalance & Independent & Independent & Independent \\
Financial deflation (bust) & Conflicting & Independent & Complementary \\
\hline
\end{tabular}

Source: Authors' elaboration.

10. See Dubecq, Mojon and Ragot (2010).

11. See Taylor (2009) and Obstfeld and Rogoff (2009).

12. See Yellen J. L. (2010): "Macro-prudential Supervision and Monetary Policy in the Post-crisis World." Remarks at the Annual Meeting of the National Association for Business Economics, October, 11. 


\section{Lessons from Model-Based Simulations}

In this section we use model-based simulations to identify the circumstances under which macro-prudential and monetary policies may have compounding, neutral or even conflicting outcomes on financial and price stability. We investigate the most efficient policy mix under such circumstances.

\subsection{The Approach Followed and the Characteristics of the Models Used}

Economists typically use micro-founded models, where behavioral assumptions are invariant with respect to the policy regime, to assess the relative merits of alternative economic policies. In macroeconomics, these models are the most widely used analytical tools in order to describe the effects of alternative monetary policies on the business cycle and inflation. In this context, the decisions of consumers and firms can be described as deriving from intratemporal and inter-temporal maximization of their utility and profits given their preferences and the state of technology.

Usual assumptions are that households supply labor and allocate their income into consumption and investment within a period and over time, while firms combine labor and capital into output. In addition, it is typically assumed that all prices and wages cannot be reset every period (prices and wages are sticky) because of nominal rigidities. Such rigidities open the way to the non-neutrality of monetary policy. The most attractive feature of such models is that their behavioral patterns are independent of government policies. They can therefore be used in order to compare alternative monetary policies, or their interplay with macro-prudential policies.

These models, however, have several drawbacks (see appendix C for a comprehensive review). Their dynamic properties, and therefore the relative performance of alternative policies, depend on parameters, the estimates of which remain largely uncertain. More to the point of this paper, only recently have these models imbedded a description of the financial sector (see appendix A for a survey of this literature).

This is usually done in the following way. Credit is modeled as a determinant of either physical capital accumulation or housing investment because of the existence of some form of asymmetric 
information. Hence, borrowers can issue credit only up to the value of their collateral (see Bernanke, Gertler and Gilchrist, 1999 or Iacoviello, 2005). ${ }^{13}$ The availability and the cost of credit can influence aggregate demand, output gap and inflation. One can therefore use such models to analyze how the cyclical component of macroprudential policies, which are expected to mainly consist of leaning against credit developments, impact upon business-cycle dynamics, and therefore price stability.

As of today, only very few papers ${ }^{14}$ have proposed a formal assessment of the effects of macro-prudential policies on price stability. In a recent contribution, N'Diaye (2009) shows that raising capital requirements during periods of economic boom can dampen the financial accelerator mechanism. Hence, macro-prudential policies may facilitate the stabilization of inflation, and hence, the task of the monetary policy authority. This conclusion, however, may not hold true under all types of economic circumstances. If the economy is predominantly driven by shocks that move inflation and credit in opposite directions, then policies that aim at stabilizing credit may in turn destabilize inflation.

We describe such mechanisms in models that have been estimated over the period 1985-2010 for the euro area (see appendix B for a description of the model). These estimates provide a first assessment of the circumstances under which the pursuit of price and financial stability may be conflicting. We focus in particular on the response of inflation to the typical shocks that have driven the euro area business cycle over the last 25 years, as captured by our estimates.

\subsection{Modeling Monetary and Macro-Prudential Policies}

We then consider whether alternative policy regimes influence dynamics under these "typical economic circumstances." We focus our analysis on four archetypical policy regimes:

13. Recent contribution investigate more extensively the role of the financial structure, including a focus on bank capital (Dib, 2010; Meh and Moran, 2010; Angelini, Neri and Panetta, 2010, and references therein. See also Curdia and Woodford; de Fiore and Tristani; Karadi and Gertler; Gertler, Kiyotaki, and Queralto (2010); Brunnermeier et al. (2012) and references therein.

14. Most contributions are recent if not very recent. See Kannan, Rabanal, and Scott (2009), N'Diaye (2009), Angeloni and Faia (2010), Gerali et al. (2009), Angelini, Neri and Panetta (2010), Gertler, Kiyotaki ,and Queralto (2010), Cecchetti and Kohler (2010), and Antipa, Mengus and Mojon (2010). See also Kashyap and Stein (2010), Fahr, Rostagno, Smets, and Tristani (2010). 
A "plain vanilla" Taylor rule: this is the benchmark case where the monetary policy instrument, i.e. the short-term interest rate, follows a standard Taylor rule and is assigned the sole objective of price stability. According to this rule, the short-term nominal interest rate increases in reaction to both the inflation and the output gap.

"Lean against the financial wind" or "augmented" Taylor rule: under this regime, monetary policy leans against financial winds, i.e. the Taylor rule is augmented with an argument whereby the shortterm nominal interest rate increases with credit growth.

Independent macro-prudential policy: the two authorities conduct their policies separately and independently (i.e. non-cooperatively), focusing on their respective objective.

Finally, we consider a fourth policy regime in which the central bank factors in credit developments in its interest rate decision, that is, it follows an "augmented" Taylor rule, while an independent macro-prudential authority leans separately against the wind.

We assume that the purpose of macro-prudential policy consists mainly in "leaning against the financial winds." 1516 Therefore, a macroprudential rule involved in these third and fourth regimes specifies how a macro-prudential instrument leans against nominal credit growth. In our model, this takes the form of policy makers' ability to influence the loan-to-value ratio that enters the collateral constraint of impatient households and entrepreneurs. From a macroeconomic perspective, this is equivalent to limiting the amplitude of the deviation of aggregate credit from its steady-state value. It is indeed likely that the forthcoming macro-prudential policy could take the form of "leaning against credit," or implicitly lead to such an effect. ${ }^{17}$ Such an outcome might result from the recourse to several instruments currently under discussion for macro-prudential policies. For instance, regulations requiring that banks set aside more capital as asset prices rise would raise the interest rate margin that banks have to charge on loans over their funding

15. See footnote 1 .

16. Gertler, Kiyotaki and Queralto (2010) focus instead on the contrasting effects of subsidizing the issuance of external equity ex ante, which increases the resilience of the banking system in the event of the crisis, and the time varying threat of no public intervention in times of crisis, which increases risk-taking by the banking system as in Farhi and Tirole (2010).

17. Alessi and Detken (2009) show that persistent deviations of the credit/GDP ratio from its trend (which is akin to our steady state level of credit) are a robust leading indicator of a costly bust in the financial and real cycles. See also Borgy, Clerc and Renne (2011) for a comprehensive analysis of early warning indicators of financial, crises-led recessions. 
costs. Other instruments may contribute to this purpose, including dynamic provisioning, pro-cyclical capital or liquidity requirements, and taxation of credit or of maturity transformation. ${ }^{18}$ We abstract from the discussion of the most appropriate instruments to lean against credit, altogether, in order to focus instead on the macroeconomic effects of such stabilization policies.

Turning to the specific coefficients of the policy rules, we proceed first with a simplest initial calibration of Taylor rule for the benchmark regime, with coefficients of 1.5 on inflation and 0.5 on the output gap, ${ }^{19}$ with an autoregressive coefficient of 0.9 . The augmented Taylor rule uses an ad hoc coefficient of 0.7 on the log level of nominal credit. This magnitude is meant to have an effect of credit on the variance of the interest rate in between the variance due to inflation and that due to the output gap. In terms of the macro-prudential policy that affects directly the loan to value ratio in the model, we set $\tau=0.5$ in

$$
\theta_{t}=\bar{\theta} z_{t}^{\theta}\left(\frac{b_{t}}{\bar{b}}\right)^{-\tau}
$$

\subsection{A Typology of Shocks and Their Effects on Price Stability}

We now turn to comparing the dynamics of inflation across regimes. There exists a broad consensus that policies aimed at price and financial stability ought to be mutually reinforcing following shocks that move aggregate demand, including credit supply shocks. On the other hand, the effects on inflation of these two objectives may

18. A presentation of these options is available in the CGFS report. See also Jeanne and Korinek (2010) on the pros and cons of a Pigouvian tax on credit.

19. The larger the weights on output variability in the loss function, the more the monetary policy maker cares about output variability. In the case of the Federal Reserve, which has a double objective of full employment and price stability, we could for instance expect a higher weight than for the Eurosystem, whose mandate is primarily to focus on price stability. In the latter case we could in principle assume that only inflation variability matters to the central bank. However, as argued by Svensson (1999), even the monetary policy of a central bank that seeks to stabilize inflation can be modeled via a Taylor rule, which makes the policy rate react not only to the current (or expected) inflation rate, but also to the current (or expected) output gap, simply because the output gap is a determinant of future inflation. We do not want to take these exercises too literally because they crucially depend on model's parameters that, in general, are not precisely estimated. Our purpose is instead mainly illustrative. 
be conflicting following shocks to productivity. ${ }^{20}$ Indeed, a persistent increase in productivity can stimulate demand for houses because economic agents anticipate an increase in their future income and, provided some inertia from real wages, reduce both unit labor costs and inflation. To some extent, this corresponds to the situation of many OECD countries in the run up to the sub-prime crisis. Credit growth was very dynamic, growing much faster than GDP while inflation remained low and stable. Arguably, if inflation is indeed a monetary phenomenon, macro-prudential policies that would have slowed credit and money growth could have had the side effect of pushing inflation rates below the inflation objectives of monetary authorities, if not to negative values. Such policies could have put a threat on the anchoring of inflation expectations close to the level of the inflation objective of central banks. ${ }^{21}$

We use the estimated model in order to illustrate situations in which monetary and macro-prudential policies may either neutralize or reinforce each other. The behavioral parameters and the stochastic structure (i.e. the relative importance of shocks) are estimated over the period 1985-2010. We then compare the dynamics of economic variables across the four policy regimes listed above.

Alternative policies within one type of regime differ in terms of the strength with which the policymaker reacts to inflation, the output gap, or credit. These weights can be linked to the preferences of the authorities (see the textbooks of Woodford, 2003; Galí, 2008; and Walsh, 2010). We come back to this point later, but the main trust of the qualitative results we present here is not affected by the preferences implicitly consistent with these policy rule coefficients.

In view of the potential conflict between the objectives of price and financial stability under some circumstances, the next important question is to assess how important such shocks can be in the business cycle. This is however the object of an endless academic literature that goes beyond the scope of this paper.

A first pass on this question is to report how important such shocks were, according to our model estimates. The variance decomposition of inflation, output gap, short-term interest rate, credit and housing prices are reported in table 3 .

20. This point is also illustrated in Kannan, Rabanal and Scott (2009) and Angeloni and Faia (2010).

21. On the trade-off between financial stabilization and the cost to the credibility of the inflation objective, see the illuminating discussion of Carney (2009). 
Table 3. Variance Decomposition of the Main Euro Area Aggregates

\begin{tabular}{lccccc}
\hline & $\begin{array}{c}\text { Housing } \\
\text { pref }\end{array}$ & Productivity & $\begin{array}{c}\text { Credit } \\
\text { supply }\end{array}$ & $\begin{array}{c}\text { Cost } \\
\text { push }\end{array}$ & $\begin{array}{c}\text { Monetary } \\
\text { policy }\end{array}$ \\
\hline Credit & 5.37 & 23.37 & 49.89 & 7.29 & 5.72 \\
House price & 34.15 & 44.84 & 0.17 & 10.06 & 2.75 \\
Interest rate & 3.74 & 19.85 & 0.12 & 57.41 & 14.79 \\
Output & 1.3 & 56.19 & 0.18 & 31.04 & 7.96 \\
Inflation & 0.58 & 38.72 & 0.1 & 54.06 & 3.64 \\
\hline
\end{tabular}

Source: Authors' calculations.

Percent of total variance, only most important shocks are reported.

These variance decompositions point to those shocks that are the most important ones. The variances of inflation are shocks to markup and productivity and to a much lesser extent, monetary policy. Hence, an authority that cares about stabilizing inflation should care mostly about the potential perturbation due to the pursuit of macro-prudential policy following such shocks. However, this variance decomposition may not be entirely robust and we compare the dynamics of inflation for all identified shocks in the model.

In any event, the most relevant point of our analysis is to describe whether the four policy regimes imply differences in inflation dynamics. Hence, we report the response of inflation to all the estimated shocks of the model in figure 1. First, the responses of inflation to technology, cost-push and monetary policy shocks are almost identical across the four policy regimes, and these three shocks account for $90 \%$ of the variance of inflation.

The dynamics of inflation differ for other shocks. In particular, the augmented Taylor rule can be destabilizing for inflation if compared to the benchmark plain vanilla Taylor rule regime. This is the case following either the housing preference shock or the financial shock. As can be seen in figure 2, which reports the effects of a financial shock, the augmented Taylor rule implies an abrupt increase in the real interest rate, which turns out destabilizing for output and inflation. In contrast, the combination of a standard Taylor rule and a target macro-prudential rule (in the policy regime 3 ) turns out both more stabilizing for credit (figures 3 and 4) and non-destabilizing for inflation. 
Figure 1. Inflation Dynamics across Policy Regimes Inflation
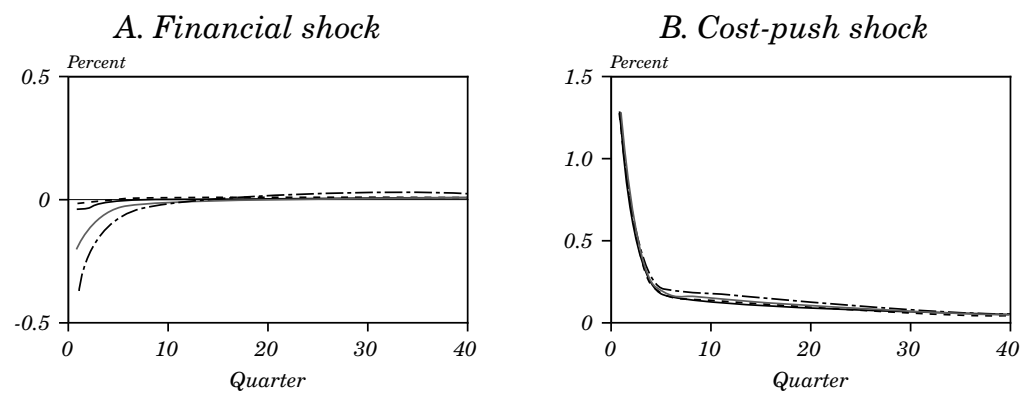

C. Housing shock

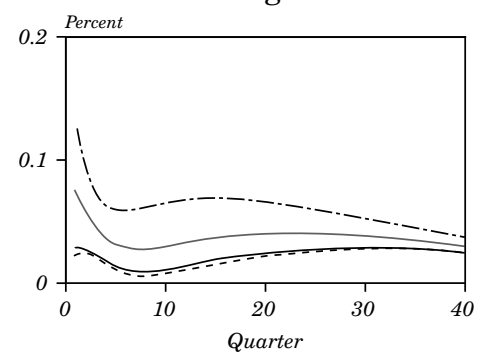

D. Monetary shock

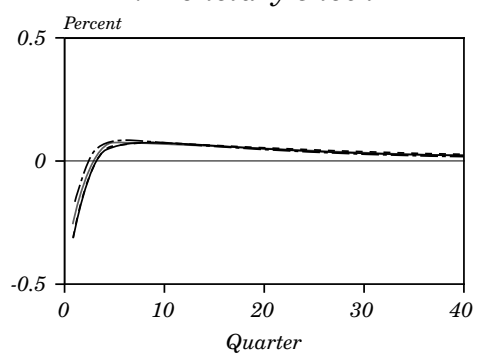

E. Technology shock

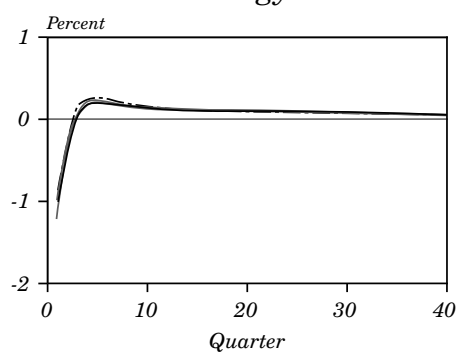

F. Investment shock

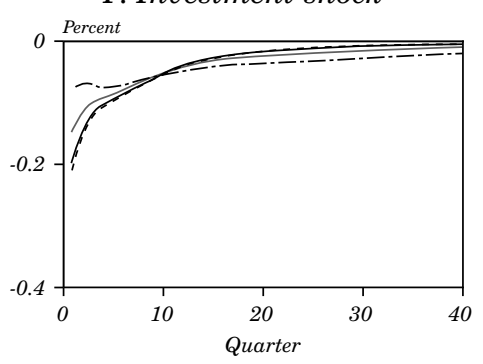

— Taylor Rule _-._. AugmentedTR

MacroPrudential

- ATRandMacroPrud

Source: Authors' elaboration. 
Figure 2. Effects of a Financial Shock (Credit Supply) across Policy Regimes

Financial shock

A. Inflation

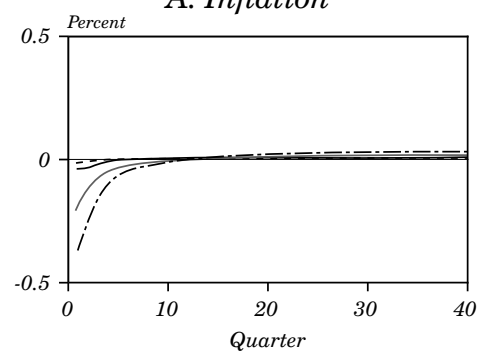

C. Credits

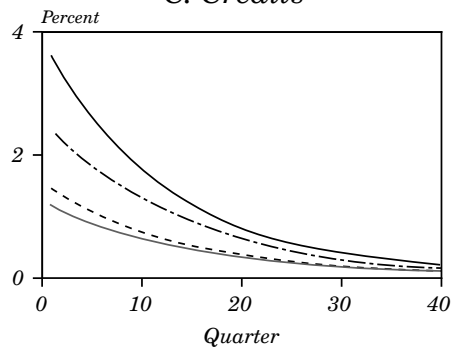

E. Housing prices

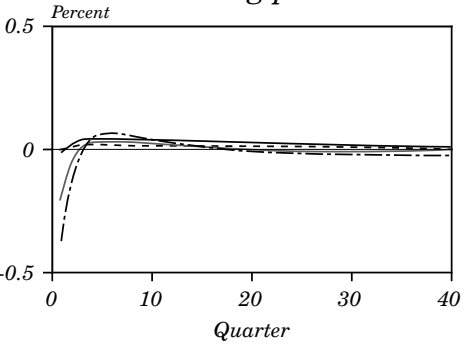

G. Real interest rate

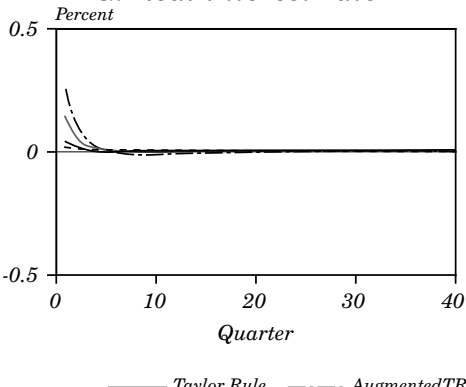

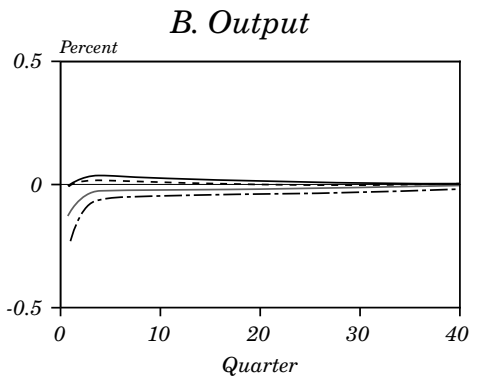

D. Policy rate

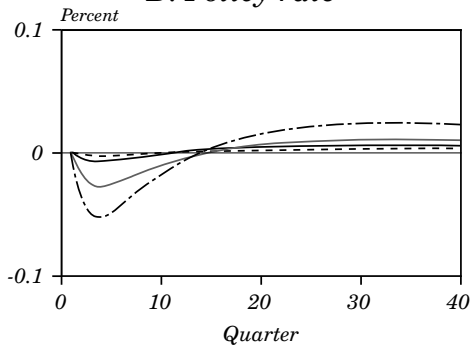

F. Consumption

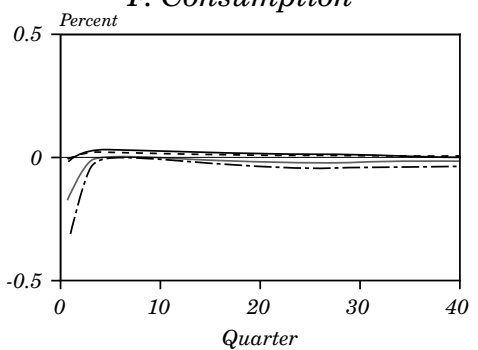

H. Hhs housing

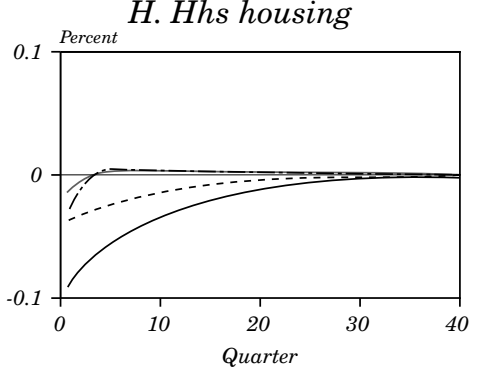

Source: Authors' elaboration. 
Figure 3. Effects of a Productivity Shock across Policy Regimes

Tecnology shock
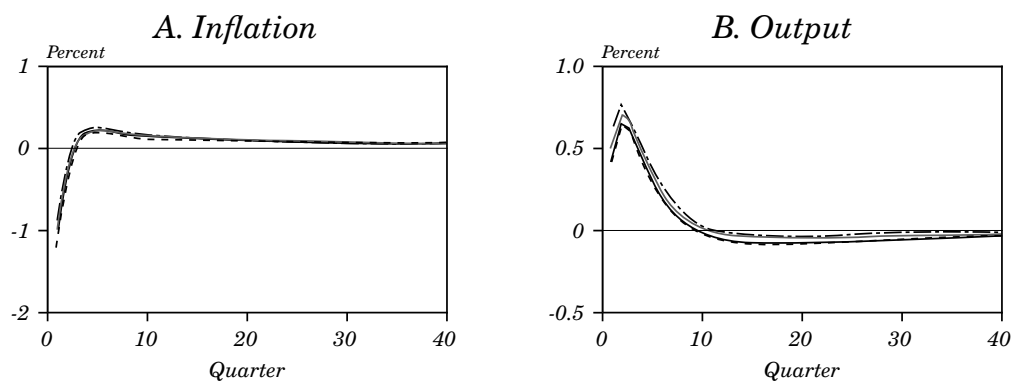

C. Credits

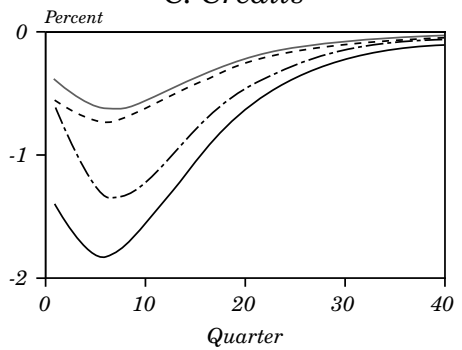

D. Policy rate

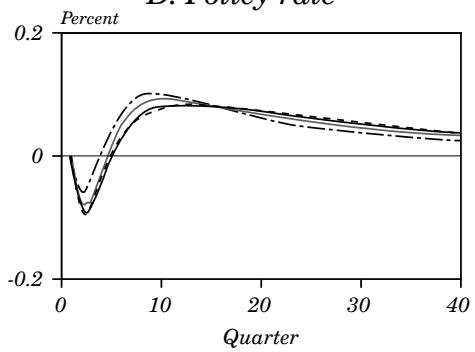

E. Housing prices

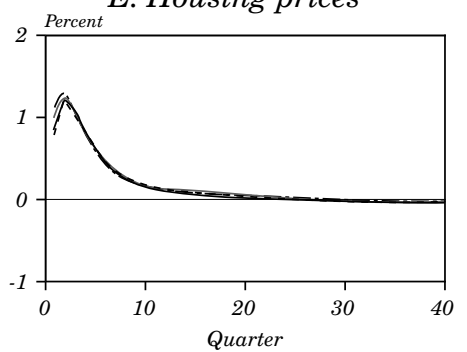

F. Consumption

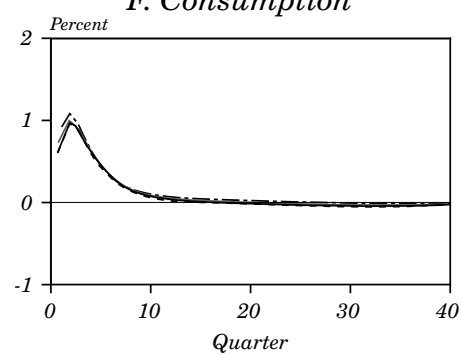

G. Real interest rate
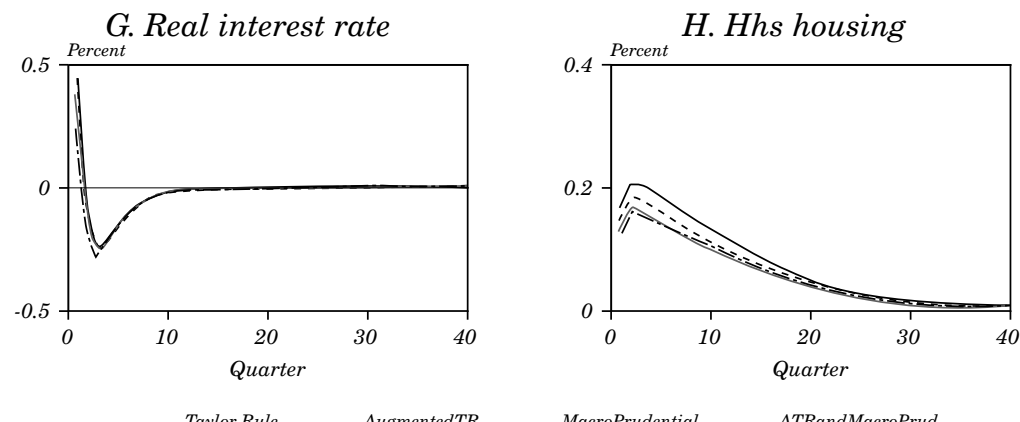

Source: Authors' elaboration 
Figure 4. Effects of a Monetary Policy Shock across Policy Regimes

Monetary shock

A. Inflation

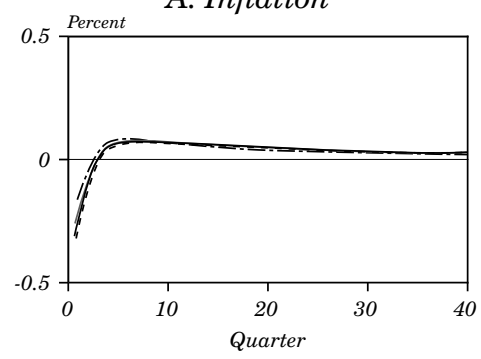

C. Credits

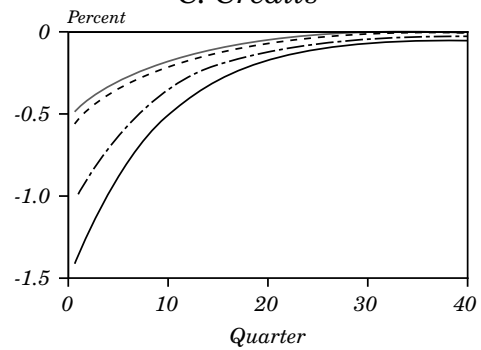

E. Housing prices

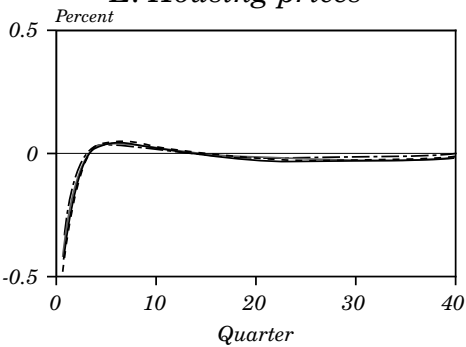

G. Real interest rate

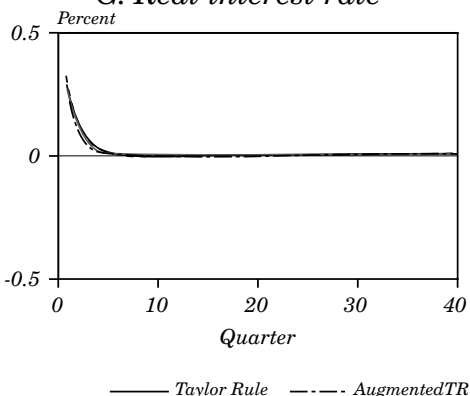

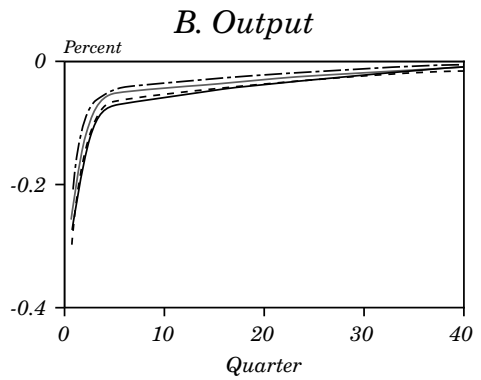

D. Policy rate

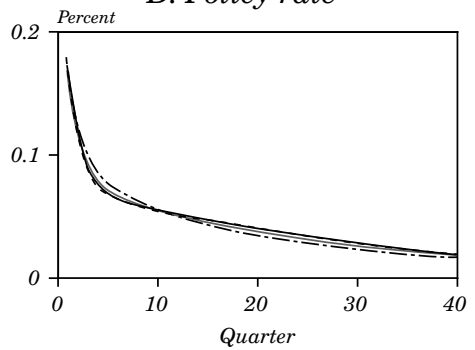

F. Consumption

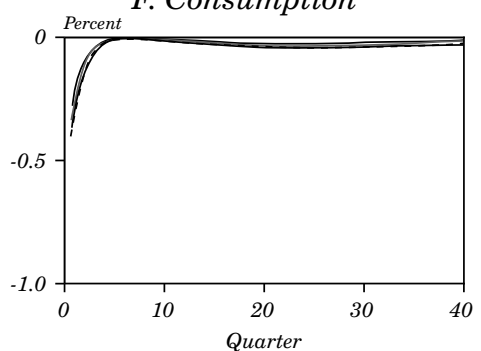

H. Hhs housing

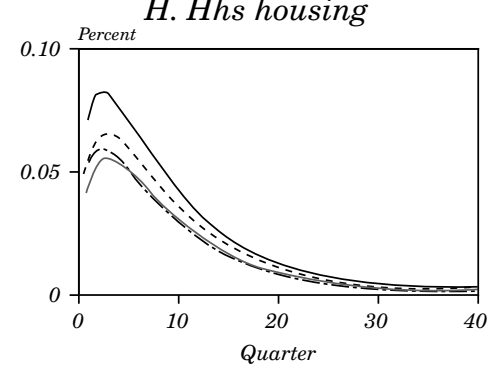

Source: Authors' elaboration. 


\subsection{Limiting the Amplitude of Boom-Bust Cycles}

We now turn to the model to analyze whether macro-prudential policies would limit the amplitude of boom-bust cycles. The experiment we conduct this time takes the form of a deterministic simulation of the model for two levels of steady state loan-to-value (LTV) ratios. First, we design a sequence of financial shocks to obtain a plausible boom-bust cycle of credit, meant to replicate the recent Spanish financial cycle, which in this case the steady state LTV ratio is 0.7 . Our benchmark credit cycle is the deviation of Spanish bank credit to the private sector, from its HP trend, between 2006 and 2012 .

Second, we input the exact same sequence of shocks to a version of the model where the steady state LTV ratio is 0.35 .

The results, reported in figure 5 , show a much more muted credit cycle in the model with half the LTV ratio (see the impulse response in red), as could be expected. The trajectory of output deviation from trend is also much more limited for a smaller LTV ratio. However, the experiment also shows that the response of output to the financial shock seems implausibly high in view of the Spanish experience. The impulse responses of inflation, the interest rate and house prices (not reported for the sake of space) show much less instability in the model with smaller LTV ratio.

\section{Conclusion}

In this paper, we analyze how macro-prudential policy interactions may affect the conduct and performance of monetary policy. First we discuss the set-up of institutions in charge of macro-prudential policy in the U.S. and in Europe and the potential conflict that this new policy may have with monetary policy.

We then assess whether macro-prudential and monetary policies may have compounding, neutral or conflicting effects on financial and price stability. According to an econometric approach relying on a DSGE model estimated for both in the euro area, we show that episodes of conflict should, on average, be rather limited over the business cycle. These conflicts depend on the nature of the shocks impacting on the economy. Over the period under review (19852009), both the credit and the housing preference shocks, which are the most relevant for macro-prudential policies, on average, only 


\section{Figure 5. Counterfactual on Macro-Prudential Policies}

A. Credits-trend deviation

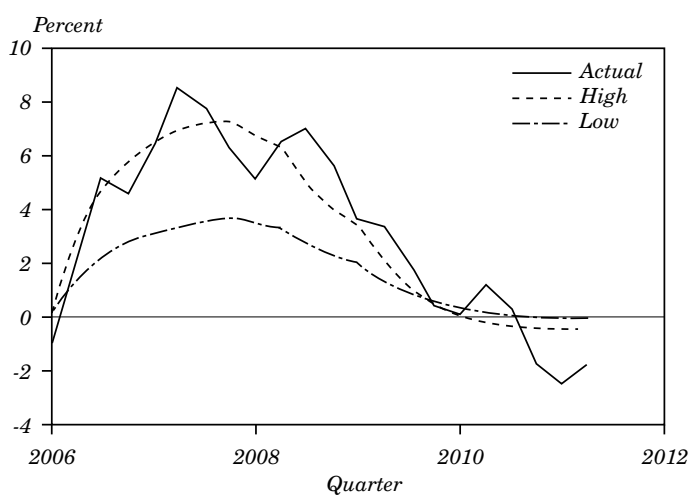

B. Output-trend deviation

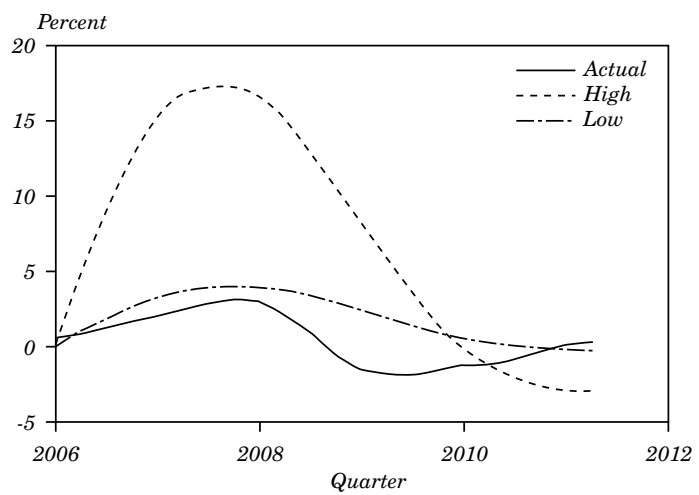

Source: Authors' elaboration.

marginally accounted for inflation dynamics. And for the shocks that have explained most of the fluctuation in inflation, whether monetary policy leans against financial winds or not, and whether we have an additional macro-prudential policy instrument active or not, hardly makes any difference for the dynamics of inflation.

Assuming that such a finding is robust across different sample periods and countries, this means that the implementation of macroprudential policy should not be overly harmful to monetary policy. 
298 Denis Beau, Christophe Cahn, Laurent Clerc, and Benoît Mojon

Quite the contrary, it may even facilitate the latter by offsetting the transmission of financial disturbances to the real economy. This assumes however that the macro-prudential authority is able to counter the propagation of destabilizing asset price and credit supply shocks to the real economy by leaning against credit. 


\section{REFERENCES}

Alessi, L. and C. Detken. 2009. "Real Time Early Warning Indicators for Costly Asset Price Boom-Bust Cycles.” Working Paper 1039, European Central Bank.

Angelini, P., S. Neri, and F. Panetta. 2010. "Grafting Macroprudential Policies in a Macroeconomic Framework, Choice of Optimal Instruments and Interaction with Monetary Policy." Unpublished manuscript, Banca d'Italia.

Angeloni, I. and E. Faia. 2009. "Tale of Two Policies: Prudential Regulation and Monetary Policy with Fragile Banks." Kiel Working Papers 1569.

Antipa, P., E. Mengus, and B. Mojon. 2010. "Would Macro-prudential Policies Have Prevented the Great Recession?" Unpublished manuscript, Banque de France.

Altunbas, Y., L. Gambacorta, and D. Marqués-Ibáñez. 2010. "Does Monetary Policy Affect Bank Risk-Taking?” Working Paper 1166, European Central Bank.

Bernanke, B., M. Gertler, and S. Gilchrist. 1999. "The Financial Accelerator in a Quantitative Business Cycle Framework." In Taylor, J.B., Woodford, M. (Eds.), Handbook of Macroeconomics, edited by J.B. Taylor and M. Woodford. Amsterdam: Elsevier Science.

Borgy, V., L. Clerc, and J.P. Renne. 2011. "Measuring Aggregate Risk: Can We Robustly Identify Asset-price Boom-bust Cycles?" Unpublished manuscript, Banque de France.

Borio, C. and H. Zhu. 2008. "Capital Regulation, Risk-Taking, and Monetary Policy: A Missing Link in the Transmission Mechanism?" Working Paper 2588, Bank for International Settlements.

Brownlees C. and R. Engle. 2010. "Volatility, Correlation and Tails for Systemic Risk Measurment." WP NYU-Stern.

Brunnermeier M.K. and L. H. Pedersen, 2009. "Market Liquidity and Funding Liquidity." Review of Financial Studies, 22(6): 2201-2238.

Brunnermeier, M.K., T. Eisenbach, and S. Yuliy. 2012. "Macroeconomics with Financial Frictions: A Survey." Unpublished manuscript, Princeton University.

Carney, M. 2009. "Some Considerations on Using Monetary Policy to Stabilize Economic Activity." Remarks by Mr Mark Carney, Governor of the Bank of Canada, to a symposium sponsored by the Federal 
Reserve Bank of Kansas City, Jackson Hole, Wyoming, 22 August. Carlstrom, C.T. and T.S. Fuerst. 1997. "Agency Costs, Net Worth, and Business Fluctuations: A Computable General Equilibrium Analysis." American Economic Review 87: 893-910.

Cecchetti, S., H. Genberg, J. Lipsky, and S. Wadhwani. 2000. "Asset Prices and Central Bank Policy." Geneva Reports on the World Economy 2. Geneva: International Centre for Monetary and Banking Studies.

Cecchetti, S. and M. Kohler. 2010. "On the Equivalence of Capital Adequacy and Monetary Policy." Unpublished manuscript, Bank for International Settlements.

Christiano, L., R. Motto, and M. Rostagno. 2007. "Shocks, Structures or Monetary Policies? The Euro Area and U.S. after 2001." Working Paper 774, European Central Bank.

Ciccarelli, M., A. Maddaloni, and J.L. Peydró. 2009. "Trusting the Bankers: Another Look at the Credit Channel of Monetary Policy." Unpublished manuscript, European Central Bank.

Committee on the Global Financial System. 2010. "Macro-prudential Instruments and Frameworks: A Stock Taking of Issues and Experiences." CGFS Papers 38, May.

De Graeve, F. 2008. "The External Finance Premium and the Macroeconomy: U.S. Post-WW II Evidence." Journal of Economic Dynamics and Control 32(11): 3415-3440.

De Nicolo, G., G.D. Ariccia, L. Laeven, and F. Valencia. 2010. "Monetary Policy and Bank Risk Taking." IMF Staff position note, July.

De Walque, G., O. Pierrard, and A. Rouabah. 2008. "Financial (In) Stability, Supervision and Liquidity Injections : A Dynamic General Equilibrium Approach.” Research series 200810-23, National Bank of Belgium.

Dib, A. 2010. "Banks, Credit Market Frictions, and Business Cycles." Document de Travail 2010-24, Bank of Canada.

Dubecq, S., B. Mojon, and X. Ragot. 2010. "Fuzzy Capital Requirements, Risk Shifting and the Risk Taking Channel of Monetary Policy." NER 254, Banque de France.

Fahr, S., M. Rostagno, F. Smets, and O. Tristani. 2010. "A Monetary Policy Strategy in Good and Bad Times.” Working Paper 1336, European Central Bank.

Faia, E. and T. Monacelli. 2007. "Optimal Interest Rate Rules, Asset Prices and Credit Frictions." Journal of Economic Dynamics and Control 31(10): 3228-3254.

Gerali, A., S. Neri, L. Sessa, and F. Signoretti. 2009. "Credit and 
Banking in a DSGE Model of the Euro Area." Unpublished manuscript, Banca d'Italia.

Gilchrist, S., A. Ortiz, and E. Zakrajsek. 2009. "Credit Risk and the Macroeconomy: Evidence from an Estimated DSGE Model.” Unpublished manuscript, U.S. Federal Reserve Board.

Hollo, D., M. Kremer, and M. Lo Duca. 2010. "CISS: A Composite Indicator of Systemic Stress in the Financial System." Working Paper 1426, European Central Bank.

Iacoviello, M. 2005. "House Prices, Borrowing Constraints, and Monetary Policy in the Business Cycle." American Economic Review 95(3): 739-64.

Kannan, P., P. Rabanal, and A. Scott. 2009. "Monetary and MacroPrudential Policy Rules in a Model with House Price Booms.” Working Paper 251, International Monetary Fund.

Kashyap, A. and J. Stein. 2012. "The Optimal Conduct of Monetary Policy with Interest Rate on Reserves." American Economic Journal: Macroeconomics, 4(1): 266-282.

Kiyotaki, N. and J. Moore . 1997. "Credit Cycles." Journal of Political Economy 105(2): 211-48.

Liu, Z., P. Wang, and T. Zha. 2009. "Do Credit Constraints Amplify Macroeconomic Fluctuations?” Working Paper Series 2009-28, Federal Reserve Bank of San Francisco.

Meh, C. and K. Moran. 2010. "The Role of Bank Capital in the Propagation of Shocks." Journal of Economic Dynamics and Control 34(3): 555-576.

Modigliani, F. and M. Miller. 1958. "The Cost of Capital, Corporation Finance and the Theory of Investment." American Economic Review 48(3): 261-97.

Mundell R. 1962. "The Appropriate Use of Monetary and Fiscal Policy for Internal and External Stability." Staff papers 9, International Moneatary Fund.

Rajan, R. 2005. "Has Financial Development Made the World Riskier?" Presented at: The Greenspan Era: Lessons for the Future, a symposium sponsored by the Federal Reserve Bank of Kansas City, Jackson Hole, Wyoming, August 25-27.

Svensson, L.E.O. 1999. "Inflation Targeting as a Monetary Policy Rule." Journal of Monetary Economics 43: 607-54.

Townsend, R. 1979. "Optimal Contracts and Competitive Markets with Costly State Verification." Journal of Economic Theory 21(2): 265-93. 


\section{APPENDIX A}

\section{Literature Review: Financial Frictions and Canonical Macro-Models}

Canonical macroeconomic models mostly incorporate the assumption of frictionless financial markets. Based on the ModiglianiMiller (1958) theorem, these models imply that the composition of agents' balance sheets has no effect on their optimal spending decision. Thus, canonical macro models have difficulties accounting for the feedback between financial conditions and the real economy in times of financial distress.

One of the first contributions to have challenged the ModiglianiMiller theorem is the seminal article by Bernanke, Gertler and Gilchrist (1999), henceforth BGG. In this framework, borrowers face an external finance premium, which reflects the different costs of internally and externally raised funds. The finance premium inversely depends on borrowers' net worth, which is pro-cyclical due to the pro-cyclicality of profits and asset prices. This entails that the external finance premium is countercyclical, enhancing the swings in borrowing and hence investment and aggregate demand. The external finance premium therefore propagates shocks to the real economy and amplifies business cycle fluctuations.

Gilchrist, Ortiz and Zakrajsek (2009) incorporate a proxy of the external finance premium in a DSGE model estimated on U.S. data over the period 1973-2008. The authors find an operative financial accelerator, i.e. increases in the external finance premium cause important and protracted contractions in investment and output. De Graeve (2008) provides for an estimate of the external finance premium, which is on an average of 130 basis points over the postWWII period. ${ }^{22}$

Another type of framework focusing on borrowers' balance sheets goes back to the work of Kiyotaki and Moore (1997). In this set-up, lenders cannot force borrowers to reimburse their debt. Thus, durable assets such as land and machinery play a dual role

22. When taking the data to the model, the author finds that for some shocks (such as investment supply shocks) the finance premium is not countercyclical. This may give rise to a financial decelerator mechanism corroborated also by the results of Iacoviello (2005) and Christiano, Motto and Rostagno (2007), see further below for more details. 
being used as factors of production and collateral for loans at the same time. Borrowers' credit lines are consequently affected by the collateralized assets' prices and collateral constraints govern borrowers' investment and spending decisions, which in turn affect asset prices then again. The dynamic interaction between credit limits and asset prices function as a transmission mechanism by which the effects of financial shocks persist, is amplified and spills over to other sectors.

Liu, Wang and Zha (2009) estimate a DSGE model with U.S. data and show that the amplification mechanism in Kiyotaki and Moore (1997) is empirically important. This study finds positive co-movements between housing prices and business investment. A shock to housing demand-affecting the marginal rate of substitution between housing and consumption-generates important macroeconomic fluctuations, accounting for $36-46 \%$ and $22-38 \%$ of the fluctuations in investment and output, respectively.

One implication of the above-described models is that borrowing constraints are always binding, in which case default never occurs in equilibrium. In contrast, in Carlstrom and Fuerst's (1997) analysis, ${ }^{23}$ agency costs are endogenous over the business cycle and default emerges as an equilibrium phenomenon. Consequently, there is room for regulatory policies. Based on this framework, Faia and Monacelli $(2007)^{24}$ address the question of whether monetary policy should react to asset prices, answering it affirmatively. More precisely, in their setting, asset price movements are caused by financial distortions since the price of capital is determined in a lending market characterized by moral hazard, i.e. the asset price is subject to a tax. In the case of a positive productivity shock, this wedge evolves pro-cyclically, thereby restraining investment. For an increase in asset price, monetary policy should therefore react by lowering the nominal interest rate. This result may seem controversial; however, it also hinges on the metric that is used to evaluate the performance of different policy rules. While policy rules are usually assessed considering the volatility of inflation and output, here the selection is based on strict welfare criteria.

23. Based on the costly state verification model by Townsend (1979).

24. The authors succeed in generating a countercyclical behavior of the external finance premium by assuming that the mean distribution of investment outcomes across lenders depends on the state of aggregate productivity: the pro-cyclicality of the external finance premium in Carlstrom and Fuerst (1997) initial analysis being a very counterintuitive result. 
In a recent paper, Iacoviello (2005) combines a financial accelerator mechanism à la BGG with collateral constraints tied to real estate values in the spirit of Kiyotaki and Moore (1997). A third rigidity is added to this framework, debt contracts are denominated in nominal terms. This allows considering the distributional consequences of nominal rigidities as in Fisher (1933). The Fisher debt deflation channel amplifies effects of shocks that drive output and the price level in the same direction, such as positive demand shocks, ${ }^{25}$ and dampens the impact of shocks that drive output and the price level in opposite directions. Finally, Iacoviello finds that responding to asset prices does not improve output and inflation stabilization.

The above-mentioned studies consider the demand side of financial frictions, i.e. borrowers' balance sheets. Arguably, supply side factors may have a substantial impact on the business cycle; that is to say that a bank's balance sheet might affect the transmission of shocks. Christiano, Motto and Rostagno (2007) incorporate a banking sector into a DSGE model containing also a debt-deflation channel. As in Iacoviello, the authors find that financial accelerator/ decelerator mechanisms depend on the nature of shocks. Moreover, quantitatively, financial frictions according to BGG. are an important driving force of business cycle fluctuations, both in the euro area and the U.S. When it comes to the transmission and amplification of shocks, these frictions play a substantially bigger role than the incorporated banking sector. Finally, in this set-up, output volatility is stabilized when broad monetary aggregates are taken into account; reacting to the stock market is stabilizing for the U.S. economy but not so for the euro area.

Meh and Moran (2010) construct a dynamic general equilibrium model in which the balance sheet of banks affects the propagation of shocks. ${ }^{26}$ Key to the propagation of shocks in this model is the banks' capital adequacy ratio. Although it arises from market discipline, the simulations give insights on its cyclical properties: whether capital adequacy ratios ought to be pro-cyclical or if it will depend on the

25. For a positive demand shock, consumer and asset prices increase. This reduces the real value of outstanding debt, positively affecting borrowers' net worth. Simultaneously, the rise in asset prices augments the borrowing capacity of the debtors, allowing them to spend and invest more. As borrowers have a higher propensity to spend than lenders, the net effect on demand is positive, and acts as an amplification mechanism for the initial shock.

26. At the heart of the propagation mechanism lays a double moral hazard problem seen in Holstrom and Tirole (1997). 
nature of shocks. Following technology and monetary policy shocks, capital adequacy ratios vary negatively with the cycle, possibly exacerbating the business cycle. When disturbances originate within the banking sector (i.e. sudden drops in bank capital) capital adequacy ratios are pro-cyclical: capital adequacy ratios loosen just as output weakens. Finally, independent of the shock's nature, economies whose banking sectors remain well capitalized experience smaller reductions in bank lending, and hence less severe downturns. Bank capital thus increases an economy's ability to absorb shocks and, in doing so, affects the conduct of monetary policy.

Finally, De Walque, Pierrard and Rouabah (2008) model on interbank market, populated by heterogeneous banks. In their framework, agents, including banks, can default on their financial obligations. Here, endogenous default rates generate a countercyclical risk premium acting as a financial accelerator. Their framework is particularly interesting because monetary policy takes the form of liquidity injections into the interbank market. The authors find that a central bank's liquidity injections lead to less financial instability (measured by the ratio of repayment of funds borrowed on the interbank market). However, in terms of output volatility, liquidity injections have an ambiguous effect.

Only few models explicitly account for macro-prudential policies in a broader sense. One of them is Kannan, Rabanal and Scott (2009). The authors examine the potential role of monetary policy in mitigating the effects of asset price booms. Results imply that stronger monetary reactions to signs of overheating, or a credit or asset price bubble, could help counter accelerator mechanisms that push up credit growth and asset prices (in line with what Cecchetti, Genberg, Lipsky and Wadhwani, 2000 argue). However, this is only the case when shocks are of a financial character. For technology shocks, a standard Taylor rule still does best in terms of reducing volatility in output and inflation.

Gerali, Neri, Sessa, and Signoretti (2009) provide for the only up to date DSGE model incorporating a banking sector, estimated on euro area data. Here, banks enjoy some degree of market power (in both the loan and the deposit markets) and accumulate capital subject to a capital adequacy requirement. Due to the interest rate setting behaviour of banks the model accounts for an intermediation spread. This spread alters the pass-through of changes in the policy rate to bank rates, usually at work in standard models with endogenous borrowing constraints but without financial 
intermediation. ${ }^{27}$ Overall, the authors find that banking induces some attenuation on output, mainly reflecting the presence of sticky interest rates. Banking nonetheless enhances the persistence in real variables in response to technology shocks. Finally, the authors assess the contribution of financial shocks to the crisis experienced since 2007 and find that almost all the contraction of real GDP was due to factors that either pushed up the cost of credit or reduced the amount of credit available to the private sector.

Angelini et al. (2010) introduce interactions and sequencing between monetary and macro-prudential policies, the latter seeking to stabilize the loans/GDP ratio and GDP growth. The paper's preliminary results so far do not hint an important quantifiable aspect of strategic interactions between monetary and macroprudential policy makers. However, interactions seem to play a role for the cyclicality of the macro-prudential rules tested in the analysis.

Finally, Angeloni and Faia (2009) provide for another framework allowing the study of interactions between bank regulation and monetary policies in fragile banking systems (i.e. when bank runs are possible). Given this framework, households' welfare is optimized by a combination of countercyclical capital ratios and a monetary policy response to asset prices.

27. The overall effect of intermediation is affected by the stickiness of interest rates (banks translate changes in interest rates only partially) inducing some attenuation. On the other hand, the credit market power and the ensuing mark-up between lending rates and policy rates amplifies changes in the policy rate for borrowers, while the markdown between the policy rate and the deposit rate attenuate effects for lenders. 


\section{ApPendix B}

\section{The Euro Area Model Used for Simulations}

In section 2 of this paper, we rely on a modified version of the models estimated by Antipa, Mengus and Mojon (2010), in which we consider impatient entrepreneurs and patient (or Ricardian) households only. The model is a DSGE seen in Iaccoviello (2005) with residential investment, house prices and housing loans. It should be stressed that, in the model, housing prices influence the investment cycle as in Liu et al. (2009).

\section{The Private Sector}

Only housing shocks intervene in agents' utility functions. In our specification, patient households are subject to the marginal utility of housing that in turn affects housing demand. Contrary to Iacoviello (2005) where changes to the marginal substitution between housing and consumption affect both patient and impatient households, here we are interested in the interactions between a demand shock on one hand and a biting, borrowing constraint in a framework of nominal debt indexation on the other hand.

Formally, housing preference shocks intervene on $\varphi_{t}$ in the constrained households' utility function:

$$
E_{0} \sum_{t=0}^{\infty}\left(\beta^{R}\right)^{t}\left(\log \left(C_{t}\right)+\varphi_{t} \log \left(L_{t}^{h}\right)-\frac{1}{1+\eta}\left(N_{t}\right)^{1+\eta}\right)
$$

where $C_{t}, L_{t}^{h}$ and $N_{t}$ are consumption, housing and hours worked respectively.

The ordering in time preferences is the following: entrepreneurs are more impatient than patient households $\left(\beta^{E}=0.975 ; \beta^{R}=0.9943\right.$, see Gerali et al., 2009). We take $\eta=1$.

The other distinctive feature of this model is the borrowing constraints for entrepreneurs. Entrepreneurs maximize their utility subject, not only to a standard inter-temporal budget constraint, but also to a borrowing constraint that will be binding at equilibrium. This borrowing constraint is given by:

$R_{t} B_{t}^{E} \leq \theta_{t} E_{t}\left(q_{t+1} L_{t}^{E}\right)$ 
where $E_{t}\left(q_{t+1}\right)$ is the expected house price in $t+1$ and $L_{t}^{E}$ is the entrepreneur's holdings in housing wealth, and $\theta_{t}=\bar{\theta} z_{t}^{\theta}$ the loan-tovalue ratio with $z_{t}^{\theta}$ an $\operatorname{AR}(1)$ shock ( $\bar{\theta}=0.35$ as in Iacoviello, 2005). Borrowing is thus limited to the net present discounted value of housing wealth. A positive financial shock, $z_{t}^{\theta}$, can therefore be understood as a relaxation of entrepreneurs loan to value ratio (caused by an increase in competition in the banking sector or financial innovation for instance). These constraints are binding equalities at equilibrium.

The model was estimated for the euro area based on quarterly observations from 1997:IV to 2011:II. The observables used for the estimation are GDP, consumption, residential investment, inflation, the money market rate, housing loans and the house prices. Observations are used in first difference of logged variables, except for housing prices time series, which is used in fourth difference to get rid of seasonal variations. Only the parameters relative to the shocks (standard deviation and persistence coefficients) and the monetary policy reaction function are estimated through bayesienne procedure. The remaining parameters are calibrated according to previous studies. The estimated parameters are reported at the end of the present appendix. Dynare codes used for the estimation and simulations are available upon request from the authors.

\section{Government Policies}

Following a standard approach, we evaluate the potency of MP policies by simulating the effects of various shocks in the model across three of the four archetypical policy regimes listed in section 2.1:

\section{The Plain Vanilla Taylor Rule}

This reaction function of the central bank reflects the adjustment of level of short-term interest rates in response to lagged deviations of inflation, and output, from their respective steady state values. The relationship can be expressed as

$r_{t}=\left(1-\gamma_{R}\right)\left[\gamma_{\pi} \hat{\pi}_{t-1}^{C}+\gamma_{y} \hat{y}_{t-1}\right]+\gamma_{R} r_{t-1}+z_{t}^{r}$

where $\gamma_{R}$ denotes the inertia of interest rates and $\gamma_{\pi}, \gamma_{y}$ are the coefficients assigned to the reactions to the inflationary and output gaps, respectively. $z_{t}^{r}$ denotes an AR(1) monetary shock. 


\section{Lean Against the Wind Taylor Rule}

In this second policy regime, the central bank also raises interest rates in reaction to the growth rate of credit. The monetary policy rule can then be expressed as

$r_{t}=\left(1-\gamma_{R}\right)\left[\gamma_{\pi} \hat{\pi}_{t-1}^{C}+\gamma_{y} \hat{y}_{t-1}+\gamma_{b} \hat{b}_{t-1}\right]+\gamma_{R} r_{t-1}+z_{t}^{r}$

where $\hat{b}_{t-1}$ denotes the lagged deviation of real credit with respect to its steady state value $\left(\gamma_{b}\right.$ being the corresponding weight within the policy rule).

\section{Independent Macro-Prudential Policy}

In this third regime, we have both the same monetary policy rule as in regime 1, i.e.

$r_{t}=\left(1-\gamma_{R}\right)\left[\gamma_{\pi} \hat{\pi}_{t-1}^{C}+\gamma_{y} \hat{y}_{t-1}\right]+\gamma_{R} r_{t-1}+z_{t}^{r}$

and the lean against credit rule. The latter rule impacts upon agents' borrowing constraints by affecting their respective loan-tovalue ratios. The equation for the time-varying loan-to-value ratio, and hence the credit rule, is:

$\theta_{t}=\bar{\theta} z_{t}^{\theta}\left(\frac{b_{t}}{\bar{b}}\right)^{-\tau}$

where $z_{t}^{\theta}$ is an $\mathrm{AR}(1)$ shock to the loan-to-value ratio, and has to be understood as a credit supply shock. $b_{t}$ is the entrepreneurs' debt level ( $\bar{b}$ its steady-state level). Finally, $\tau$ governs the strength of the policy-makers reaction to excessive credit growth.

This is a combination of the plain vanilla Taylor rule and an independent policy instrument, which reacts to the growth rate of nominal credit thus constraining agents' loan-to-value ratio and hence the amount of overall credit. 
Table B1. Parameter Estimates

\begin{tabular}{|c|c|c|c|}
\hline Symbol & Description & Prior $^{a}$ & Posterior mode ${ }^{b}$ \\
\hline \multicolumn{4}{|c|}{ Shocks' persistence parameter } \\
\hline$\rho_{\varphi}$ & Housing shock & Beta $(0.8,0.05)$ & $0.9390(0.0165)$ \\
\hline$\rho_{g}$ & External/Gov. shock & Beta $(0.8,0.1)$ & $0.7911(0.0433)$ \\
\hline$\rho_{t}$ & Technology shock & Beta $(0.8,0.1)$ & $0.6821(0.0293)$ \\
\hline$\rho_{\theta}$ & Loan-to-value ratio shock & Beta $(0.8,0.1)$ & $0.9322(0.0229)$ \\
\hline$\rho_{p}$ & Cost-push shock & Beta $(0.8,0.1)$ & $0.8362(0.0093)$ \\
\hline$\rho_{i}$ & Investment shock & Beta $(0.8,0.1)$ & $0.5380(0.0558)$ \\
\hline \multicolumn{4}{|c|}{ Standard deviation of shocks' innovation } \\
\hline$\sigma_{h}$ & Housing shock & Inverse Gamma $(0.01,0.02)$ & $0.0861(0.0250)$ \\
\hline$\sigma_{g}$ & External/Gov. shock & Inverse Gamma $(0.01,0.02)$ & $0.0124(0.0012)$ \\
\hline$\sigma_{t}$ & Technology shock & Inverse Gamma $(0.01,0.02)$ & $0.0196(0.0021)$ \\
\hline$\sigma_{\theta}$ & Loan-to-value ratio shock & Inverse Gamma $(0.01,0.02)$ & $0.0239(0.0024)$ \\
\hline$\sigma_{p}$ & Cost-push shock & Inverse Gamma $(0.01,0.02)$ & $0.0040(0.0005)$ \\
\hline$\sigma_{i}$ & Investment shock & Inverse Gamma $(0.01,0.02)$ & $0.0548(0.0068)$ \\
\hline$\sigma_{r}$ & Monetary shock & Inverse Gamma $(0.01,0.02)$ & $0.0018(0.0002)$ \\
\hline \multicolumn{4}{|c|}{ Taylor rule } \\
\hline$\gamma_{\pi}-1$ & Coefficient on inflation & Inverse Gamma $(0.5,0.5)$ & $0.1278(0.0186)$ \\
\hline$\gamma_{y}$ & Coefficient on output & Normal $(0.5,0.1)$ & $0.6156(0.0756)$ \\
\hline$\gamma_{R}$ & Smoothing parameter & Beta $(0.8,0.05)$ & $0.9159(0.0133)$ \\
\hline
\end{tabular}

Source: Authors' elaboration.

a. Priors: shape (prior mean, prior standard deviation).

b. Gaussian approximation of posterior standard deviation at the mode is given in parentheses. 


\section{APPENDIX C}

\section{Limitations of the Model and of the Simulation Exercises Performed with it}

The exercise developed in this section allows us to gain insights on the interaction between monetary and macro-prudential policies. However, several limits in the analysis should be acknowledged. It is nevertheless also fair to emphasize that, although they might call for further significant developments, these limits are mainly entrenched in any modeling exercise. Consequently, most of them would also apply to a wider range of modeling exercises.

\section{Uncertainty about the model (is this DSGE model a fair representation of the actual economy?)}

Building a model involves choosing a set of simplifying assumptions. An important one is that the economy is isolated from the rest of the world. However, domestic financial stability and domestic inflation rates are affected by what happens in the rest of the world and in big foreign economies. A drawback of considering the economy as a single entity is that the issues of both the international coordination of those two policies and the quantification of their importance cannot be addressed.

Another important issue is the modeling of the financial imperfections and of their impact on the business cycle. As evident from table 2.1 and from the simulations reported in figures $3.1 \mathrm{a}$ to 3.9 , credit developments have only a limited effect on the dynamics of real and nominal variables. This could be because the financial cycle is longer lasting and more asymmetric than the real business cycle, and the models are estimated over samples during which monetary policy has managed to dampen inflation fluctuations.

More generally, the model only focuses on a specific form of credit rationing. There is no role for a fall in the demand for credit and for an increase in the savings rate, which have been observed for some agents during the crisis. Moreover, liquidity hoarding by banks is a sign of effective self-insurance on the part of some financial institutions, which is not present in the model. A new literature studies uncertainty shocks and precautionary savings (Bloom, 2009) in order to explain a fall in activity when uncertainty increases, 
which can create negative externalities. This model abstracts from all of that and, once again, focuses on only one margin.

Credit constraints capture the difficulties for entrepreneurs to get financed. Admittedly, they capture market freeze during financial turmoil, which may be linked to market liquidity. Dealing with this effect in such a reduced-form way allows to simply estimate the effect at stake, but the market failure for funding and market liquidity are different, and so is the optimal policy answer. Interactions between funding and market liquidity are studied by a recent literature (see for example Brunnermeier and Pedersen, 2009), which however does not provide quantitative insight yet.

\section{Uncertainty about the policy function objective}

The postulated policy objectives and the associated reaction functions are intuitive and tractable. However, they are not derived from primitive parameters describing the preferences of the agents the public authority aims at maximizing. In particular, it might be the case that the relative weight given to each of the target variables in the rule (or in the loss function) differs from the optimal one that these primitive parameters would imply.

\section{Uncertainty about the estimated coefficients: econometric structure (time-varying parameters, heteroskedasticity, etc.)}

Simulating the economy under different policies is based on estimated parameter values. These estimates are thus prone to estimation uncertainty, which could also be included in the simulations. More generally, tackling the uncertainty concerning the parameters' values could call for considering that the structure of the model is itself uncertain, and include this as a feature of the estimation procedure. For instance, one may allow for time-variation in either the parameters describing the transmission mechanism of the structural shocks to the macroeconomic aggregates, or the ones characterizing the variance of the structural shocks.

\section{Policy dependence of the estimated parameters (the so- called Lucas critique)}

Along the same lines, using estimated coefficients to conduct policy simulations is prone to the so-called Lucas critique. The estimation 
strategy postulates a given structure of the economy. This structure involves, among other elements, the parameters characterizing the policy reaction function. In particular, private sector's agents take their decisions conditional on this policy rule (and these specific parameters). Therefore, a shift in the policy rule may affect the structure of the economy and require re-estimating the model under the new structure. However, for this to be implementable, we would need data under a regime where macro-prudential policy already existed.

\section{Uncertainty about the data: revisions (i.e. Orphanides)}

The simulations are based on final releases of macroeconomic aggregates. By contrast, public authorities take decisions in real time and therefore rely on real-time data that are subsequently updated, and sometimes differ substantially from final figures. This is especially relevant when the economy experiences big disruptions whose consequences are difficult to interpret in real time, and thus take time to be learned. It may therefore be interesting to see how the conclusions of the exercise would differ if the policy reacted to these real-time data.

\section{Uncertainty about the central bank's (or other authority's) ability to implement the policy}

In the model, we assume in particular that the authorities can lean against credit.

a. Information (about the agents and the economy) needed to implement (optimal) policy (i.e. Orphanides and Williams)

The uncertainty behind the parameter estimates alluded above is more than just a matter of econometrics methodology. It is reasonable to assume that public authorities may have an informational advantage, compared to the private sector in monitoring and processing statistical information, and therefore have a more precise view of the evolution of the macroeconomic outlook. They nevertheless still remain uncertain about the exact structure of the economy. By comparison the proposed simulation exercise postulates that the authorities have an accurate perception of this structure. An extension would be to analyze a situation where the objective 
function of the central bank (or other authority) incorporates their own uncertainty about this complex structure. This would influence their optimal decisions (and therefore the optimal reaction function). For instance they might want to minimize the loss under the less favorable scenario induced by their approximation instead of the scenario where the economy behaves as described by the "point estimates" of the models parameter.

\section{b. Political economy}

The model considers a macro-prudential authority, which is well settled and independent from national governments. It therefore abstracts from the process of setting-up this new regulatory body. However, national or industrial vested interest may stall this process. This would pave the way for time-inconsistency problems due to non-credible commitments to restrict credit growth when the macroeconomic outlook calls for it. 